\title{
A Decision Support Technique to Design Solar Power System for Sindh Agriculture University Tandojam
}

\author{
Zulfiqar Ali Effendi* Mrs. Aisha Kousar** Aziza Aftab Memon*** \\ *Lecturer IEEM Mehran University of Engineering and Technology Jamshoro \\ ** Lecturer Chemical Department Mehran University of Engineering and Technology Jamshoro \\ *** Assistant Professor Chemical Department Mehran University of Engineering and Technology Jamshoro
}

\begin{abstract}
Pakistan's energy requirements are increasing day by day and not only economic growth but political stability is linked with the availability of energy resources. At present the total generation installed capacity is 21,000 MW. The peak demand is 15,000 MW, but the production is only 9,000-10,000 MW, resulting in 10-12 hours of load shedding. The root cause of the faulty fuel mix is the use of furnace oil as the main fuel to produce thermal electricity. This energy crisis has destroyed at least 50 percent of the industrial sector that has led to increase in the rate of unemployment. It has badly affected the fixed income group because costs of goods and services have increased. Due to the electricity crises a common man look to the available short term alternatives such as generators and Uninterrupted Power Supply (UPS) units but they are not environmental friendly nor have enough storing capacity to provide continuous energy. Due to above problems, the report has been formulated which divert the attention of the policy makers of Sindh Agriculture University Tandojam for bringing the university to the solar system. This process was done using both software and manual analysis, to determine the tilt angle, azimuth degrees, Photovoltaic module size, size of the inverters, batteries and charge controller. At the other hand we also estimated the cost efficiency of solar power system as compare to HESCO in which we analyze the basic appliances like tube lights, savers, fans and computers. The total load of the all faculties and departments are 3, 51,498 Watts per month and the monthly expenditure are paid by university is Rs.11,59,943. But as compare to solar power system the monthly expenditure for same load is just Rs.2, 68,504 and it has a 25 years life as well. If we compare the HESCO and solar power system we would save approximately $76.8 \%$ monthly cost. The result of this study can be referred by the policy makers and decision takers of Government and as well as private sectors. We all are causing the problem of pollution, but we need to realize that there are many other power sources for running appliances, and that these options need to be taken advantages.
\end{abstract}

\section{Energy crises Scenario of Pakistan}

\section{Introduction}

Pakistan has been facing an energy crisis since 2007. The main reason for the current crisis is that in the past no efforts were made to ensure increase in power generation capacity along with increase in population growth. An energy crisis is any great shortfall in the supply of energy resources to an economy. Electricity is the basic need of human life. It has great importance as it is directly related to every country's economy.

Pakistan's energy requirements are increasing day by day and not only economic growth but political stability is linked with the availability of energy resources. At present the total generation installed capacity is $21,000 \mathrm{MW}$. The peak demand is $15,000 \mathrm{MW}$, but the production is only 9,000-10,000 MW, resulting in 10-12 hours of load shedding. The root cause of the faulty fuel mix is the use of furnace oil as the main fuel to produce thermal electricity. The months of January to May have very low hydropower available since reservoirs are empty and snow melt will not, start till June. The Tarbela reservoir receives about 95 percent of its water through snow melt. The natural gas is in short supply and is available only to produce 29 percent MW of electricity. As over 50 percent of current generation is dependent on furnace oil, it is not viable for the government to purchase and provide oil at such high price. Therefore, many plants are either shut or transfer the cost to consumer. When the price of electricity is raised, the whole economy gets disturbed as a result of producing much below their capacity. Wapda and KESC purchase expensive oil and inflation and increase in the price of items of everyday use.

Energy crisis has destroyed at least 50 percent of the industrial sector that has led to increase in the rate of unemployment. It has badly affected the fixed income group because costs of goods and services have increased.

The current shortage of electricity of Pakistan clearly implies failure on the part of the government to tackle it. Corruption is another major reason. The government should have developed electricity through alternative resources of energy like nuclear energy, natural gas exploration, natural gas import, solar energy, coal and wind energy. 
Due to the electricity crises a common man looked to the available short term alternatives such as generators and Uninterrupted Power Supply (UPS) units. Generators are expensive to buy (average cost Rs 37,500 and per year average for five years comes out to Rs 7,500) and expensive to operate, at an average of Rs 5,882 per month and an annual cost of Rs 70,560. The noise and air pollution they cause is damaging to health and buyer don't like to visit market when there is no light.

The UPS on the other hand is cheaper at Rs 15,000 for five years but the cost of the battery is 15000 and its life is 12 months and per year average comes out to 4,000 but with an average running and maintenance cost of Rs 12,240. Moreover, it has a running cost of Rs 1,000 per month.

However, UPS does not store enough energy to meet the long hours of load shedding and also consumes a considerable amount of energy from the grid. In addition, its acid batteries cause immense air pollution which is difficult to tolerate for a long period of time.

Due to above problems, different people conducted surveys in which they wanted to know the real diversion of people to the reliable alternative system. Ninety percent of the people were showed their willing to adopt a solar energy option because they understand it's environmental and sustainability advantage. People expressed their concerns as well. Interestingly, they believe that the constraints in providing alternative energy to their units are not of a financial or technical nature but have more concerned with governance issues.

Minimum $10 \mathrm{~km} / \mathrm{hr}$ wind velocity is required for the installation of wind mill at that site but here at Tandojam i.e. $2 \mathrm{~km} / \mathrm{hr}$ velocity of wind there for wind mill is not recommended. Pakistan, has capacity of producing 350,000 MW, 2.9 million MW, $2500 \mathrm{MW}$ wind energy in coastal areas, solar Energy and Geothermal respectively. (source: Alternative Energy Development Board Ministry of Water and Power Government of Pakistan

Due to above facts the report has been formulated which divert the attention of the policy makers of Sindh Agriculture University Tandojam for bringing the university to the solar system. Further this project get more advantage when government provide subsidy on the import of silica based glass solar panels and frequent trainings must be provide regarding the assembly and the maintenance of solar panels/products.

\section{Objective of the study}

To help the decision makers for bringing the Sindh Agriculture University Tandojam from HESCO to Solar Power System.

\section{Estimation tool}

For the estimation of electric load, solar panel array sizing, solar charge controller sizing, and battery bank seizing for SAU Tandojam electric load calculator has been used.

Diagram-1 Electric lo ad Calculator

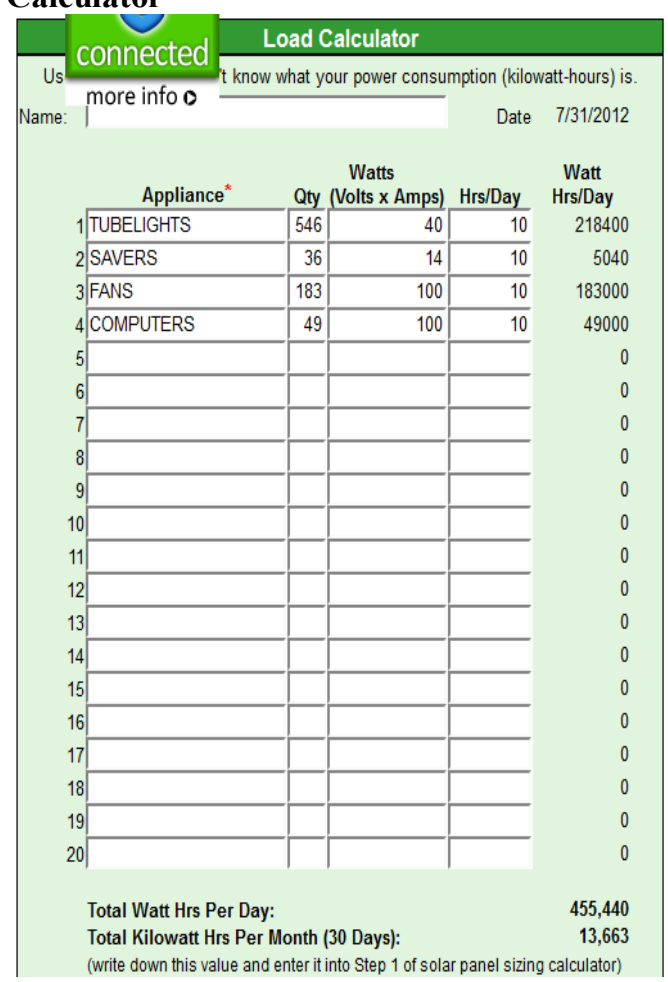




\section{Diagram-2 Solar Panel Array Sizing}

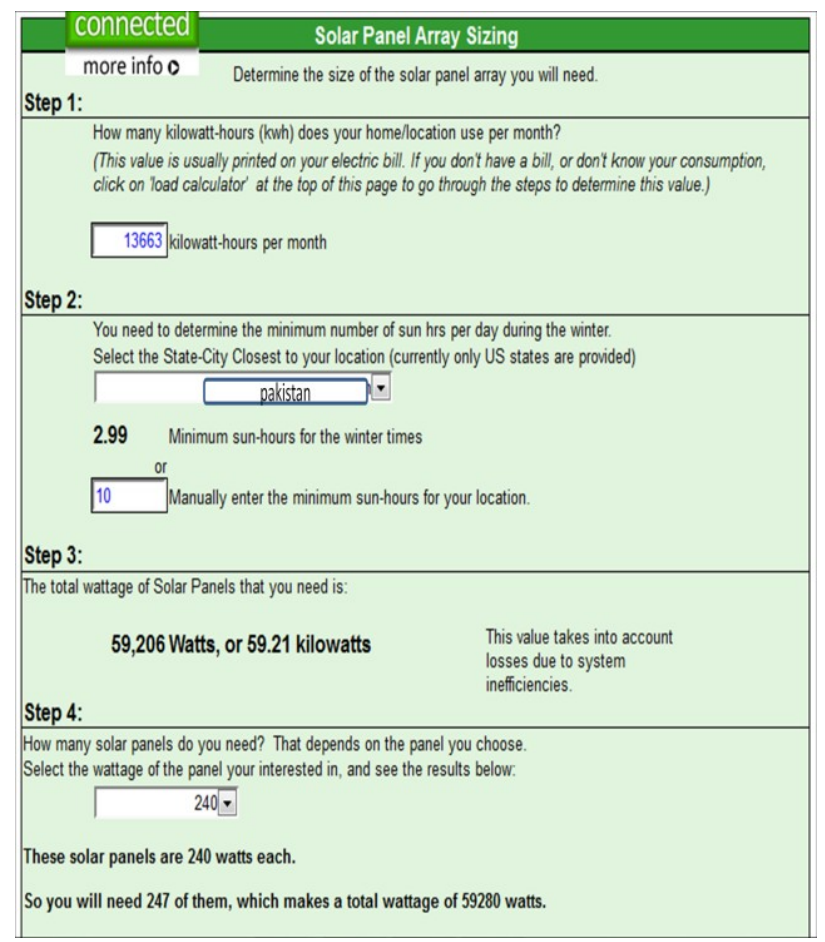

\section{Diagram-3 Solar Charge Controller Sizing}

\section{Solar Charge Controller Sizing}

This calculator helps you size the solar charge controller(s) needed for your system.

Step 1:

Wattage of solar panel array: 59280 Watts

(taken from the preious calculation of solar panels)

Step 2:

Choose the voltage of your battery bank:

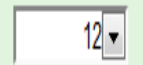

Step 3:

You will need a charge controller(s) that can suppoot at least:

\subsection{Amps}

Special Note:

Since your amperage is greater then 60 amps, you will need to wire at least 83 controllers in

The maximum size charge controller we offer is 60 amps 


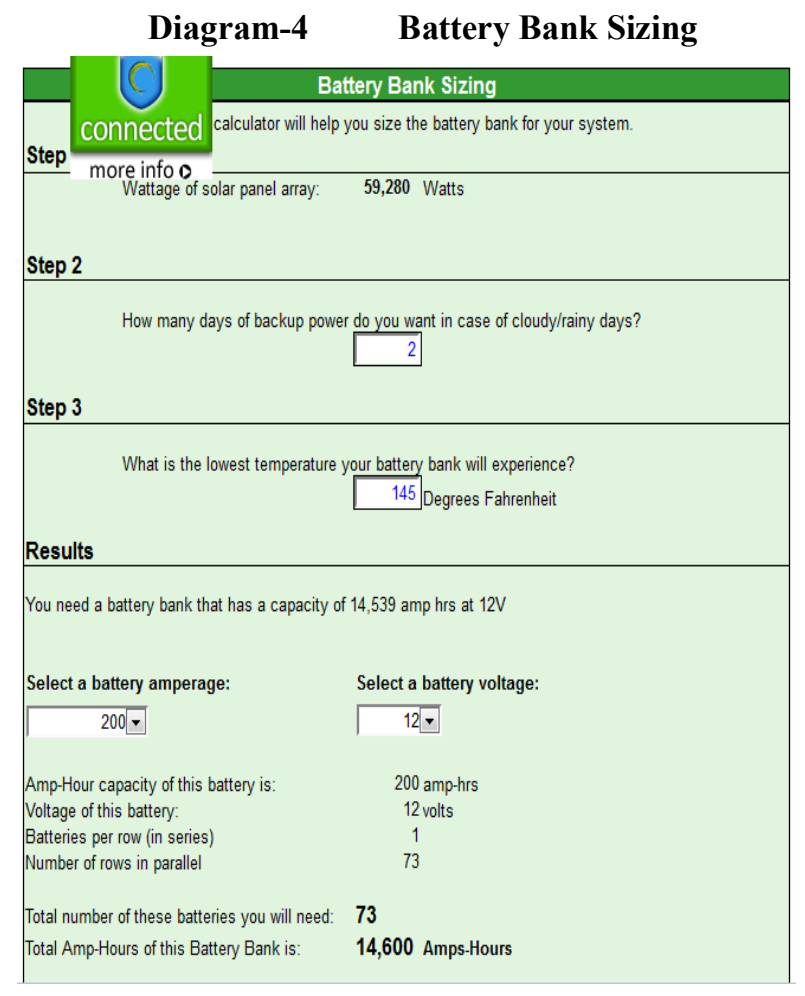

\section{Design of PV System for SAU Tandojam}

First time an Agriculture College associated with Agriculture Research Institute was established at Sakrand in District Nawabshah in 1939-40, and named as the King George-V Institute of Agriculture and This college paved the way for raising the status of the college to the full-fledged university on 1st March, 1977, named as Sindh Agriculture University, Tando Jam established under Act of 1977. Now the following faculties are prevailed in the university.

\section{- $\quad$ Faculties of the University}

Faculty of Agricultural Engineering

Faculty of Agricultural Social Science

Faculty of Crop Production

Faculty of Animal Husbandry and Veterinary Sciences

Faculty of Crop Protection

\section{- Institutes of the University}

Information technology Center

Institute of Food Sciences and Technology

- $\quad$ Farm Power Machinary Workshop

- Central Library

- $\quad$ Administration Block

\section{Faculty of Agriculture Engineering}

A total electric load of 45544 Watts was consumed by Faculty of Agricultural Engineering comprises of 22344 Watts in lights, 18300 Watts in fans and 4900 Watts in computers.

\section{Design of Solar System}

\begin{tabular}{|l|l|}
\hline Solar Panels \\
\hline No of solar panels required & 247 N0 \\
\hline Capacity of single solar panel & 240 Watts \\
\hline Solar panel produce & 59280 Watts \\
\hline Cost of each panel & 36000 \\
\hline Total cost of solar panel & RS: $88,92,000$ \\
\hline Charge Controller & \\
\hline
\end{tabular}




\begin{tabular}{|c|c|}
\hline \multicolumn{2}{|c|}{ One charge controller of $4940 \mathrm{amps}$ is required } \\
\hline Cost & RS: 350,000 \\
\hline \multicolumn{2}{|l|}{ Batteries } \\
\hline Required Amp:s & 15000 AMP/HRS \\
\hline Battery Capacity & 2OO AMP/HRS \\
\hline No of batteries for system & 75 OF 12Volt each \\
\hline Batteries cost & $\begin{array}{l}75 * 13000(\text { Cost })= \\
9,75,000\end{array}$ \\
\hline Batteries backup & 2 Days \\
\hline \multicolumn{2}{|l|}{ Inverter } \\
\hline Inverter Capacity & 6000 Watts \\
\hline Required no & 10 \\
\hline Total capacity & $10 * 6000=60,000$ \\
\hline Cost of one inverter & RS: 87,984 \\
\hline Cost of 10 invertors & RS: $8,79,840$ \\
\hline Total cost & RS: $1,08,49,840$ \\
\hline & Or 10.85 million \\
\hline
\end{tabular}

\section{Cost benefit statement}

\begin{tabular}{|c|c|}
\hline Hydropower System & Solar Power System \\
\hline $\begin{array}{l}\text { Power of Faculty }=45544 \\
\text { Watts }\end{array}$ & For Solar $=59280$ Watts \\
\hline Current of Faculty $101.87 \mathrm{Amp}$ & Monthly cost of solar system \\
\hline Monthly bill is Rs: $1,50,295$ & \\
\hline \multicolumn{2}{|l|}{ Difference is Rs: $1,14,624 /=$} \\
\hline 77 percent cost & \\
\hline
\end{tabular}

\section{Faculty of Agriculture Social Science}

A total electric load of 21716 Watts was consumed by Faculty of Agricultural Social Science comprises of 14416 Watts in lights, 6800 Watts in fans and 500 Watts in computers.

\section{Design of Solar System}

\begin{tabular}{|c|c|}
\hline \multicolumn{2}{|l|}{ Solar Panels } \\
\hline No of solar panels required & $118 \mathrm{~N} 0$ \\
\hline Capacity of single solar panel & 240 Watts \\
\hline Solar panel produce & 28320 Watts \\
\hline Cost of each panel & 36000 \\
\hline Total cost of solar panel & RS: $42,48,000$ \\
\hline \multicolumn{2}{|l|}{ Charge Controller } \\
\hline \multicolumn{2}{|c|}{ One charge controller of $2360 \mathrm{amps}$ is required } \\
\hline Cost & RS: 250,000 \\
\hline \multicolumn{2}{|l|}{ Batteries } \\
\hline Required amp:s & 7200 AMP/HRS \\
\hline Batery Capacity & $2 \mathrm{OO} \mathrm{AMP} / \mathrm{HRS}$ \\
\hline No of batteries for system & 36 OF 12Volt each \\
\hline Batteries cost & $36 * 13000($ Cost $)=4,68,000$ \\
\hline Batteries backup & 2 Days \\
\hline \multicolumn{2}{|l|}{ Inverter } \\
\hline Inverter Capacity & 6000 WATTS \\
\hline Required no & 5 \\
\hline Total capacity & $5 * 6000=30,000$ \\
\hline Cost of one inverter & RS: 87,984 \\
\hline Cost of 10 invertors & RS: $4,39,920$ \\
\hline \multirow[t]{2}{*}{ Total cost } & RS: $52,87,920$ \\
\hline & Or 5.287 million \\
\hline
\end{tabular}




\section{Cost benefit statement}

\begin{tabular}{|l|l|}
\hline Hydropower System & Solar Power System \\
\hline $\begin{array}{l}\text { Power of Faculty }=21716 \\
\text { Watts }\end{array}$ & For Solar =28320 Watts \\
\cline { 1 - 1 } Current of Faculty 48.57 Amp & $\begin{array}{l}\text { Monthly cost of solar system } \\
\text { RS:17,385/= }\end{array}$ \\
\cline { 1 - 1 } Monthly bill is RS: $71,665 /=$ & \\
\cline { 1 - 1 } Difference is Rs: $54,281 /=$ \\
\hline 76 percent cost will be saved per month \\
\hline
\end{tabular}

\section{Faculty of Crop Production}

A total electric load of 48876 Watts was consumed by Faculty of Agricultural Crop Production comprises of 21416 Watts in lights, 25000 Watts in fans and 3800 Watts in computers.

\section{Design of Solar System}

\begin{tabular}{|c|c|}
\hline \multicolumn{2}{|l|}{ Solar Panels } \\
\hline No of solar panels required & $265 \mathrm{~N} 0$ \\
\hline Capacity of single solar panel & 240 Watts \\
\hline Solar panel produce & 63600 Watts \\
\hline Cost of each panel & 36000 \\
\hline Total cost of solar panel & RS: $95,40,000$ \\
\hline \multicolumn{2}{|l|}{ Charge Controller } \\
\hline \multicolumn{2}{|c|}{ One charge controller of $5300 \mathrm{amps}$ is required } \\
\hline Cost & RS: $4,00,000$ \\
\hline \multicolumn{2}{|l|}{ Batteries } \\
\hline Required amp:s & 16000 AMP/HRS \\
\hline Batery Capacity & 2OO AMP/HRS \\
\hline No of batteries for system & 80 OF 12Volt each \\
\hline Batteries cost & $\begin{array}{l}80 * 13000(\mathrm{COST})= \\
10,40,000\end{array}$ \\
\hline Batteries backup & 2 Days \\
\hline \multicolumn{2}{|l|}{ Inverter } \\
\hline Inverter Capacity & 6000 Watts \\
\hline Required no & 11 \\
\hline Total capacity & $11 * 6000=66,000$ \\
\hline Cost of one inverter & RS: 87,984 \\
\hline Cost of 10 invertors & RS: $9,67,824$ \\
\hline \multirow[t]{2}{*}{ Total cost } & RS: $1,19,47,824$ \\
\hline & Or 11.947 million \\
\hline
\end{tabular}

\section{Cost benefit statement}

\begin{tabular}{|l|l|}
\hline Hydropower System & Solar Power System \\
\hline Power of Faculty= 48876 Watts & For Solar =63600 Watts \\
\hline Current of Faculty 112.32 A & Monthly cost of solar system \\
\cline { 1 - 2 } Monthly bill is RS: $1,65,715 /=$ & RS:39,280/= \\
\hline Difference is Rs: $1,26,435 /=$ \\
\hline 77 percent cost will be saved per month \\
\hline
\end{tabular}

\section{Faculty of Animal Husbandry and Veterinary Sciences}

A total electric load of 79692 Watts was consumed by Faculty of Animal Husbandry and Veterinary Sciences comprises of 41334 Watts in lights, 34200 Watts in fans and 5000 Watts in computers.

\section{Design of Solar System}

\begin{tabular}{|l|l|}
\hline Solar Panels \\
\hline No of solar panels required & 432 N0 \\
\hline Capacity of single solar panel & 240 Watts \\
\hline Solar panel produce & 103680 Watts \\
\hline
\end{tabular}




\begin{tabular}{|l|l|}
\hline Cost of each panel & 36000 \\
\hline Total cost of solar panel & RS: $1,55,52,000$ \\
\hline Charge Controller & RS:6,00,000 \\
\hline \multicolumn{2}{|l|}{ One charge controller of 8640amps is required } \\
\hline Cost & 26000 AMP/HRS \\
\hline Batteries & 2 OO AMP/HRS \\
\hline Required amp:s & 130 OF 12 Volt each \\
\hline Batery Capacity & $130 * 13000($ Cost $)=$ \\
\hline No of batteries for system & $16,90,000$ \\
\hline Batteries cost & 2 Days \\
\hline Batteries backup & 6000 Watts \\
\hline Inverter & 17 \\
\hline Inverter Capacity & $17 * 6000=1,02,000$ \\
\hline Required no & RS: 87,984 \\
\hline Total capacity & RS: $14,95,728$ \\
\hline Cost of one inverter & RS: $1,93,37,728$ \\
\hline Cost of 10 invertors & Or 19.34 million \\
\hline Total cost & \\
\hline &
\end{tabular}

\section{Cost benefit statement}

\begin{tabular}{|l|l|}
\hline \multicolumn{1}{|c|}{ Hydropower System } & Solar Power System \\
\hline Power of Faculty $=80534$ Watts & For Solar $=103680$ Watts \\
\hline Current of Faculty $180.14 \mathrm{~A}$ & $\begin{array}{l}\text { Monthly cost of solar system } \\
\text { RS:63,576/= }\end{array}$ \\
\hline Monthly bill is RS: $2,65,760 /=$ & \\
\hline Difference is Rs: $2,02,184 /=$ \\
\hline 76 Percent cost will be saved per month \\
\hline
\end{tabular}

\section{Faculty of Crop Protection}

A total electric load of 24230 Watts was consumed by Faculty of Crop Protection comprises of 11530 Watts in lights, 11200 Watts in fans and 1500 Watts in computers.

\section{Design of Solar System}

\begin{tabular}{|l|l|}
\hline \multicolumn{2}{|l|}{ Solar Panels } \\
\hline No of solar panels required & 132 N0 \\
\hline Capacity of single solar panel & 240 Watts \\
\hline Solar panel produce & 31680 Watts \\
\hline Cost of each panel & 36000 \\
\hline Total cost of solar panel & RS: $47,52,000$ \\
\hline Charge Controller & RS:2,00,000 \\
\hline One charge controller of 2640amps is required \\
\hline Cost & 7800 AMP/HRS \\
\hline Batteries & 2 OO AMP/HRS \\
\hline Required amp:s & 39 OF 12 Volt each \\
\hline Batery Capacity & $39 * 13000($ Cost $)=$ \\
\hline No of batteries for system & $5,07,000$ \\
\hline Batteries cost & 2 Days \\
\hline Batteries backup & 6000 Watts \\
\hline Inverter & 3 \\
\hline Inverter Capacity & $3 * 6000=18000$ \\
\hline Required no & RS: 87,984 \\
\hline Total capacity & RS: $2,63,952$ \\
\hline Cost of one inverter & RS:57,22,952 \\
\hline Cost of 10 invertors & Or 5.723 million \\
\hline Total cost & \multicolumn{2}{|l|}{} \\
\hline &
\end{tabular}




\section{Cost benefit statement}

\begin{tabular}{|l|l|}
\hline Hydropower System & Solar Power System \\
\hline Power of Faculty $=24,230$ Watts & For Solar =31,680 Watts \\
\hline Current of Faculty 54.19 A & $\begin{array}{l}\text { Monthly cost of solar system } \\
\text { RS:18,815/= }\end{array}$ \\
\cline { 1 - 1 } Monthly bill is RS: 79,959/= & \\
\hline \multicolumn{2}{|l}{ Difference is Rs 61,144/= } \\
\cline { 1 - 1 } 76.4 Percent cost will be saved per month \\
\hline
\end{tabular}

III. Institute of Food Sciences and Technology

A total electric load of 27714 Watts was consumed by Institute of Food Sciences and Technology comprises of 15114 Watts in lights, 9200 Watts in fans and 3400 Watts in computers.

\section{Design of Solar System}

\begin{tabular}{|c|c|}
\hline \multicolumn{2}{|l|}{ Solar Panels } \\
\hline No of solar panels required & $115 \mathrm{~N} 0$ \\
\hline Capacity of single solar panel & 240 Watts \\
\hline Solar panel produce & 27600 Watts \\
\hline Cost of each panel & 36000 \\
\hline Total cost of solar panel & RS: $41,40,000$ \\
\hline \multicolumn{2}{|l|}{\begin{tabular}{|l|} 
Charge Controller \\
\end{tabular}} \\
\hline \multicolumn{2}{|c|}{ One charge controller of $2300 \mathrm{amps}$ is required } \\
\hline Cost & RS: $1,80,000$ \\
\hline \multicolumn{2}{|l|}{ Batteries } \\
\hline Required amp:s & $6800 \mathrm{AMP} / \mathrm{HRS}$ \\
\hline Batery Capacity & $2 \mathrm{OO} \mathrm{AMP} / \mathrm{HRS}$ \\
\hline No of batteries for system & 34 OF 12Volt each \\
\hline Batteries cost & $34 * 13000($ Cost $)=4,42,000$ \\
\hline Batteries backup & 2 Days \\
\hline \multicolumn{2}{|l|}{ Inverter } \\
\hline Inverter Capacity & 6000 Watts \\
\hline Required no & 5 \\
\hline Total capacity & $5 * 6000=30,000$ \\
\hline Cost of one inverter & RS: 87,984 \\
\hline Cost of 10 invertors & RS: $4,39,920$ \\
\hline \multirow[t]{2}{*}{ Total cost } & RS:48,05,992 \\
\hline & Or 4.806 million \\
\hline
\end{tabular}

\section{Cost benefit statement}

\begin{tabular}{|l|l|}
\hline Hydropower System & Solar Power System \\
\hline Power of Faculty= 16752 Watts & For Solar =21840 Watts \\
\hline Current of Faculty 37.47 A & $\begin{array}{l}\text { Monthly cost of solar system } \\
\text { RS:12,904/= }\end{array}$ \\
\hline Monthly bill is RS: $55,286 /=$ & \\
\hline Difference is Rs: $42,382 /=$ & \\
\hline 77 Percent cost will be saved per month \\
\hline
\end{tabular}

\section{Institute of Information Technology Centre (ITC)}

A total electric load of 29134 Watts was consumed by Institute of Information Technology (ITC) comprises of 11634 Watts in lights, 7600 Watts in fans and 9900 Watts in computers. 


\section{Design of Solar System}

\begin{tabular}{|c|c|}
\hline \multicolumn{2}{|l|}{ Solar Panels } \\
\hline No of solar panels required & 134 N0 \\
\hline Capacity of single solar panel & 240 Watts \\
\hline Solar panel produce & 3160 Watts \\
\hline Cost of each panel & 36000 \\
\hline Total cost of solar panel & RS: $48,24,000$ \\
\hline \multicolumn{2}{|l|}{ Charge Controller } \\
\hline \multicolumn{2}{|c|}{ One charge controller of $2680 \mathrm{amps}$ is required } \\
\hline Cost & RS: $2,00,000$ \\
\hline \multicolumn{2}{|l|}{ Batteries } \\
\hline Required Amp:s & $8000 \mathrm{AMP} / \mathrm{HRS}$ \\
\hline Batery Capacity & $2 \mathrm{OO} \mathrm{AMP} / \mathrm{HRS}$ \\
\hline No of batteries for system & 40 OF 12 Volt each \\
\hline Batteries cost & $\begin{array}{l}40 * 13000(\mathrm{COST})= \\
5,20,000\end{array}$ \\
\hline Batteries backup & 2 Days \\
\hline \multicolumn{2}{|l|}{ Inverter } \\
\hline Inverter Capacity & 6000 Watts \\
\hline Required no & 5 \\
\hline Total capacity & $5 * 6000=30,000$ \\
\hline Cost of one inverter & RS: 87,984 \\
\hline Cost of 10 invertors & RS: $4,39,920$ \\
\hline \multirow[t]{2}{*}{ Total cost } & RS: $59,83,920$ \\
\hline & Or 5.98 million \\
\hline
\end{tabular}

\section{Cost benefit statement}

\begin{tabular}{|l|l|}
\hline Hydropower System & Solar Power System \\
\hline $\begin{array}{l}\text { Power of } \\
\text { Faculty=29134Watts }\end{array}$ & For Solar =32160 Watts \\
\cline { 1 - 2 } $\begin{array}{l}\text { Current of Faculty } \\
\text { 65.17Amp }\end{array}$ & $\begin{array}{l}\text { Monthly cost of solar } \\
\text { system RS:19,673/= }\end{array}$ \\
\cline { 1 - 2 } Monthly bill is RS:96,142/= & \\
\cline { 1 - 1 } Difference is Rs: 76,469/= \\
\hline 80 Percent cost will be saved per month \\
\hline
\end{tabular}

Farm Power Machinery Workshop

A total electric load of 7674 Watts was consumed by Farm Power Machinery Workshop comprises of 2374 Watts in lights, 5200 Watts in fans and 100 Watts in computers.

\section{Design of Solar System}

\begin{tabular}{|l|l|}
\hline Solar Panels \\
\hline No of solar panels required & 42 N0 \\
\hline Capacity of single solar panel & 240 Watts \\
\hline Solar panel produce & 10080 Watts \\
\hline Cost of each panel & 36000 \\
\hline Total cost of solar panel & RS: $15,12,000$ \\
\hline Charge Controller & \\
\hline One charge controller of 840 Amps is required \\
\hline Cost & RS:1,50,000 \\
\hline Batteries & 2600 AMP/HRS \\
\hline Required Amp:s & 2 OO AMP/HRS \\
\hline Batery Capacity & 13 OF 12 Volt each \\
\hline No of batteries for system & $13 * 13000($ Cost $)=1,69,000$ \\
\hline Batteries cost & 2 Days \\
\hline Batteries backup & 6000 WATTS \\
\hline Inverter &
\end{tabular}




\begin{tabular}{|l|l|}
\hline Required no & 2 \\
\hline Total capacity & $2 * 6000=12,000$ \\
\hline Cost of one inverter & RS: 87,984 \\
\hline Cost of 10 invertors & RS: $1,75,968$ \\
\hline Total cost & RS:20,06,968 \\
\hline & Or 2.01 million \\
\hline
\end{tabular}

\section{Cost benefit statement}

\begin{tabular}{|l|l|}
\hline Hydropower System & Solar Power System \\
\hline $\begin{array}{l}\text { Power of Faculty }=7674 \\
\text { Watts }\end{array}$ & For Solar $=10080$ Watts \\
\cline { 1 - 2 } Current of Faculty $17.16 \mathrm{~A}$ & $\begin{array}{l}\text { Monthly cost of solar system } \\
\text { RS:6,600/= }\end{array}$ \\
\cline { 1 - 1 } Monthly bill is RS: $25,322 /=$ & \\
\hline \multicolumn{2}{|l|}{ Difference is Rs: $18,560 /=$} \\
\hline 74 percent cost will be saved per month \\
\hline
\end{tabular}

\section{Central Library}

A total electric load of $12030 \mathrm{~W}$ was consumed by Central Library comprises of $8630 \mathrm{~W}$ in lights, $1900 \mathrm{~W}$ in fans and $1500 \mathrm{~W}$ in computers.

\section{Design of Solar System}

\begin{tabular}{|l|l|}
\hline Solar Panels & $66 \mathrm{~N} 0$ \\
\hline No of solar panels required & 240 Watts \\
\hline Capacity of single solar panel & 15840 Watts \\
\hline Solar panel produce & 36000 \\
\hline Cost of each panel & RS: $23,76,000$ \\
\hline Total cost of solar panel & \multicolumn{2}{|l|}{} \\
\hline Charge Controller & RS:1,50,000 \\
\hline One charge controller of 1320 amps is required \\
\hline Cost & 4000 AMP/HRS \\
\hline Batteries & 2 OO AMP/HRS \\
\hline Required Amp:s & 20 OF 12 Volt each \\
\hline Batery Capacity & $20 * 13000($ Cost $)=2,60,000$ \\
\hline No of batteries for system & 2 Days \\
\hline Batteries cost & 6000 Watts \\
\hline Batteries backup & 3 \\
\hline Inverter & $3 * 6000=18,000$ \\
\hline Inverter Capacity & RS: 87,984 \\
\hline Required no & RS: $2,63,952$ \\
\hline Total capacity & RS:30,49,952 \\
\hline Cost of one inverter & Or 3.05 million \\
\hline Cost of 10 invertors &
\end{tabular}

\section{Cost benefit statement}

\begin{tabular}{|l|l|}
\hline Hydropower System & Solar Power System \\
\hline Power of Faculty $=12030$ Watts & For Solar $=15840$ Watts \\
\hline Current of Faculty $26.90 \mathrm{Amp}$ & Monthly cost of solar system \\
\hline Monthly bill is RS:39,699/= & RS:10,027/= \\
\hline Difference is Rs: $29,672 /=$ \\
\hline $74.7 \quad$ Percent cost will be saved per month \\
\hline
\end{tabular}

\section{Administration Block}

A total electric load of 27714 Watts was consumed by Administration Block comprises of 15114 Watts in lights, 9200 Watts in fans and 3400 Watts in computers. 


\section{Design of Solar System}

\begin{tabular}{|c|c|}
\hline \multicolumn{2}{|l|}{ Solar Panels } \\
\hline No of solar panels required & 115 N0 \\
\hline Capacity of single solar panel & 240 Watts \\
\hline Solar panel produce & 27600 Watts \\
\hline Cost of each panel & 36000 \\
\hline Total cost of solar panel & RS: $41,40,000$ \\
\hline \multicolumn{2}{|l|}{ Charge Controller } \\
\hline \multicolumn{2}{|c|}{ One charge controller of $2300 \mathrm{amps}$ is required } \\
\hline Cost & RS: $1,80,000$ \\
\hline \multicolumn{2}{|l|}{ Batteries } \\
\hline Required Amp:s & $6800 \mathrm{AMP} / \mathrm{HRS}$ \\
\hline Batery Capacity & $2 \mathrm{OO}$ AMP/HRS \\
\hline No of batteries for system & 34 OF 12Volt each \\
\hline Batteries cost & $34 * 13000($ Cost $)=4,42,000$ \\
\hline Batteries backup & 2 Days \\
\hline \multicolumn{2}{|l|}{ Inverter } \\
\hline Inverter Capacity & 6000 Watts \\
\hline Required no & 5 \\
\hline Total capacity & $5 * 6000=30,000$ \\
\hline Cost of one inverter & RS: 87,984 \\
\hline Cost of 10 invertors & RS: 4,39,920 \\
\hline \multirow[t]{2}{*}{ Total cost } & RS:48,05,992 \\
\hline & Or 4.81 million \\
\hline
\end{tabular}

\section{Cost benefit statement}

\begin{tabular}{|l|l|}
\hline Hydropower System & Solar Power System \\
\hline Power of Faculty=27714 Watts & For Solar =27600 Watts \\
\hline Current of Faculty $61.99 \mathrm{Amp}$ & Monthly cost of solar system \\
\cline { 1 - 2 } Monthly bill is RS:91,454/= & RS:15,800/= \\
\hline Difference is Rs: $75,654 /=$ \\
\hline 82.7 Percent cost will be saved per month \\
\hline
\end{tabular}

\section{Conclusion}

\begin{tabular}{|l|l|l|}
\hline $\begin{array}{l}\text { Comparison B/W HESCO \& } \\
\text { Solar Power System }\end{array}$ & $\begin{array}{l}\text { HESCO } \\
\text { RS: }\end{array}$ & $\begin{array}{l}\text { Solar } \\
\text { System }\end{array}$ \\
\hline Faculty of Agricultural Engineering & 150295 & 35671 \\
\hline Department of Social Science & 71665 & 17384 \\
\hline Faculty of Crop Production & 165715 & 39280 \\
\hline Department of Food Technology & 55286 & 12904 \\
\hline $\begin{array}{l}\text { Department of Form Power } \\
\text { Machinary }\end{array}$ & 25322 & 6762 \\
\hline DVM Faculty & 265760 & 63576 \\
\hline Central Library & 39699 & 10027 \\
\hline Faculty of Crop Protection & 79959 & 18815 \\
\hline Administration Block & 91454 & 15800 \\
\hline Information Technology & 96142 & 19673 \\
\hline Total Charges & 1041297 & 239892 \\
\hline
\end{tabular}

\section{Results}

1. This study conclude that the solar power system is $76.96 \%$ is more economical than the HESCO.

2. Total electric bill paid by Sindh Agriculture University Tandojam monthly is RS. 1041297 for above faculties and departments.

3. Here in the solar power system for the same capacity the monthly bill will be RS. $239892 /=$ the solar power system having 25 years warranty. 
4. The total bill of 25 years in HESCO will be RS.312389100/=

5. In the solar power system for 25 years it will be RS.71967600/=

6. The saving for 25 years will be RS.20421500/=

\section{Suggestions}

We suggest to the high command/policy makers of Sindh Agriculture University Tandojam to install the solar power system in Sindh Agriculture University Tandojam and use the saving amount in projects beneficial for the University.

[1]. Department of Energy Solar Site

\section{References}

[2]. www.eren.doe.gov/RE/solar.html

[3]. DeGunther, Rik. Solar Power Your Home for Dummies. Hoboken, N.J: Wiley, 2010.

[4]. EU PV Technology Platform: “A Strategic Research Agenda for Photovoltaic Solar Energy Technology". European Communities, 2007.

[5]. Florida Solar Energy Center www.fsec.ucf.edu

[6]. Frankl, P., Menichetti, E. and Raugei, M.: "Final Report on Technical Data, Costs and Life Cycle Inventories of PV Applications". Deliverable n ${ }^{\circ} 11.2$ - RS 1a of the NEEDS (New Energy Externalities Developments for Sustainability) project, 2005.

[7]. FREE TEXAS RENEWABLE ENERGY INFORMATION; fact sheet-3, Texas www.InifinitePower.org

[8]. Keshner, M. and Arya, R.: "Study of Potential Cost Reductions Resulting from Super-Large-Scale Manufacturing of PV Modules". National Renewable Energy Laboratory, 2004.

[9]. NREL'S National Center for Photovoltaics www.nrel.gov/ncpv

[10]. Sandia Laboratory photovoltaics with load calculation worksheets www.sandia.gov/pv

[11]. State Energy Conservation Office www.InfinitePower.org

[12]. Sobha, Geeta. Green Technology: Earth-friendly Innovations. New York: Rosen Pub., 2008. 